\title{
Knowledge, wisdom, and excellence in the post-COVID-19 world
}

\author{
Senaka Rajapakse ${ }^{1}$ \\ Journal of the Ceylon College of Physicians, 2021, 52, 4-7
}

I am honoured and humbled, as I take the reins as President of the Ceylon College of Physicians, in its $54^{\text {th }}$ Year. I follow in the footsteps of my predecessors, distinguished physicians who have left their footprints in the sands of time. They, with their councils behind them, have worked relentlessly over the years to bring our College to what it is today, the oldest and most distinguished body of physicians in Sri Lanka.

I thank the Past Presidents for electing me, and the fellows and members for the confidence they have placed in me. This is the highest accolade that can be bestowed upon a physician in this country. I congratulate the outgoing president $\mathrm{Dr}$ Ananda Wijewickrama, and his council for the wonderful work done under the most trying circumstances that we have had to face in our lifetime.

When I look at the new council, I see a strong and dynamic team, chosen carefully to represent the many different subspecialities, giving the CCP diversity and strength, while building strong links with the many other specialist colleges and associations in the country. What we do this year, we do as a team, sharing our ideas to take the CCP to new heights.

Today, mankind is facing its greatest challenge in a century. A world war like no other world war, against an invisible enemy, an enemy against which we have few weapons. This is not the first-time nature has turned against us in this manner, to remind us how fragile we are. The 1918-1919 Influenza pandemic, the Spanish flu, claimed an estimated 100 million lives; more lives than the two World Wars put together. COVID-19 has so far claimed 1.8 million lives.

There are scores of books and movies and songs about the wars; but human memory is such a strange thing, and human nature is so resilient, that little is remembered of a pandemic which claimed more lives than the great wars, a phenomenon described as the world's collective amnesia. There is little glory or heroism in disease, while reminiscence paints wars with false glory. The world wanted to forget the Spanish Flu, to pretend that it never happened. Just as one day, we will want to forget this awful period of history.

But for the present, across the world, this pandemic is a great war. A war we must have confidence in winning. This is a war which is fought in the hospitals, fought in the community, and in the laboratories, a war we must fight without thought of surrender. There is little glory for the soldiers of this war, no decorations or medals; no heroic doctor has ever won a Victoria Cross for saving a patient; for the physicians who battle disease, there is only the grim sadness of losing patients they fight to keep alive, and the unexpected joy of seeing a dying patient rally round and recover. We must honour and felicitate the brave soldiers of this war, the health staff across the world, our dear colleagues who risk their lives every day. We must also pay tribute to those colleagues of ours who have been victims of this great war, those who gave their lives fighting to save the lives of others.

The pandemic has brought with it, great fear. At the beginning, the fear of dying of COVID-19 gripped society; a deadly disease which would mercilessly and unexpectedly kill. Later on, people started to be afraid of being found to have COVID-19, with the fear of being stigmatised, shunned, and locked away becoming greater than the fear of being stricken with the disease itself. This is the darkest side of the pandemic. The old and sick are hiding away without seeking medical care early, and people are also dying of other diseases. Patients with chronic diseases, non-

\footnotetext{
${ }^{1}$ President, Ceylon College of Physicians 2021

Correspondence: E-mail: Senaka.ucfm@gmail.com

https://orcid.org/0000-0003-1965-6678
}

This is an open-access article distributed under the terms of the Creative Commons Attribution License, which permits unrestricted use, distribution, and reproduction in any medium, provided the original author and source are credited. 
communicable disease, and severe acute illnesses present late, or die at home. Our attention is diverted to the pandemic, with little time or resources to look after those with other maladies. Many of these deaths are preventable, and the fact that such deaths are taking place reflects the breakdown in the provision of routine medical care, which is deadlier than the pandemic itself. As physicians, we too are afraid; afraid to provide the best care to our patients for fear of contracting the disease ourselves or spreading it to our loved ones.

COVID-19 brought with it desperation. It was seen as a deadly disease with no cure, and little prospects for one, given the record science has with treating viral diseases. People had a fearsome epidemic in front of them and were not prepared to wait. Society clamoured for a quick remedy, and science failed to deliver. It showed us how unprepared we are, when faced with a deadly new disease. Is this because we are tied down with the rigors of scientific method, with the overriding principle that we should be sure that something works, and is safe, before we recommend its use? Our system of research is one which is not built for haste. Ethical safeguards, and honesty, have forced science to slow down and be cautious. This leads to the widespread use of 'gunslinger medicine'. As deaths mounted, doctors and patients rushed to use drugs and substances of dubious value without evidence for efficacy or safety. Others with vested interests, hoping to score where they could, stepped in and advocated remedies which were untested. Tens of thousands advocated the use of hydroxychloroquine after Donald Trump promoted it relentlessly, saying 'what have you got to lose'. The arguments raged on in Sri Lanka, with physicians (and surgeons!) advocating its use, and the use of many other useless substances, through desperation. And what of these numerous remedies, some advocated by many, unleashed on an unsuspecting public? Have any of these worked? No, all have failed so far. And yet, what have we got to lose? Why not try whatever might work? Do we really need to wait for the results from clinical trials?

We live in a demon-haunted world. When science falters, when fear overcomes us, demons take over, preying on our fear, surrounding us with the darkness of ignorance. In conventional times, we would hesitate to take medicines unless essential, even though we know that they have undergone rigorous testing and that all the benefits as well as side effects are known and accessible. But in times of desperation, we throw caution to the winds, with even our best scientists willing to hang onto a thread of hope, while seeking to curry favour with the advocates of dubious remedies. But are we really willing to cut corners, expose our trusting patients to unknown substances, not knowing what harm they will do, knowing in our hearts that they are probably useless?

The demons that bring us darkness can be dispelled only through science. Science is that candle in the dark. Let us not lose faith in science. Science is rigid in its making, slow and ponderous, science asks too many questions, wants too many answers. But science has delivered, time and time again, ridding us of the scourges over the ages, where dubious therapies failed. Malaria, which killed millions in the past, is now a dying disease, eradicated from our country. Smallpox is gone, many cancers can be cured, HIV is no longer deadly. All these have been achieved through science, and no other paradigm of medicine has come even close to achieving what medical science has achieved. All the changes that have been brought about, in terms of human longevity and quality of life, have been brought about by medical scientific research. Let us not undervalue it.

I believe that our College must play a bigger role in the advocacy of science and knowledge, making its voice heard, to tell the public that which is right, that which is true, denouncing that which is false, and that which is foolish. Our College should be not just a candle, but a beacon of light, to dispel the darkness.

Hope is humanity's strongest characteristic. Hope will overcome fear. Science is the flame that ignites hope. With perseverance, we will overcome. The virus will eventually vanish. We will gradually become immune, through the development of herd immunity and through vaccination. Science will win in the end, together with human tenacity. We must have faith, not in prayers, devils, or witchdoctors, but in science and scientific method.

We must guard ourselves against the temptation of being carried away by reckless claims of benefit and hold fast to our principles of scientific method. Best evidence must always be sought out, built on knowledge gained from basic sciences research. The pandemic has made us question ourselves, whether the paradigm of evidence medicine is fit for purpose to meet the unexpected challenges we may face. However, at least for now, there is no substitute for evidence generated by rigorous scientific experiment. However, we must open our minds to other paradigms, standing on the shoulders of giants, seeking to see further than our predecessors have seen. As a college, we must take leadership in research, making maximum use of the diverse skills our membership has, building networks across the country, joining academic physicians in the universities with the 
clinicians working at grassroot levels. Evidence must be generated locally, asking the right questions, seeking the answers to the specific problems we have, rather than working on what is driven by researchers in distant lands who seek to use our data to answer questions which are relevant to them, but of little use to us. We must take ownership of our research. We must also strive to achieve excellence in research, focussing on quality and not quantity. The College has an important role to play, in giving leadership and guidance with regards to research.

This year our College will focus on strengthening research, not just by providing research training and supporting funding, but through a more broad-based strategy of developing research policy for physicians in Sri Lanka; and by fostering research networks, linking academics with clinicians. Guideline development, and evidence synthesis will go hand in hand with this.

Our prime role as a college is to advance the competencies and practices of our colleagues in the field of medicine, both physicians and physician trainees. Making our colleagues more up to date and more skilled will result in better patient care, and also enhance the prestige of our profession. We will achieve this by strengthening our College's educational and training activities, throughout the year, using innovative technology and e-learning platforms to reach all our colleagues across the country. There will be increased focus on skills training, making physicians more skilled at what they do, making them competent in the latest technological skills to enhance their practice. These will be achieved through a series of innovative sessions through the year, ending with the Annual Academic Sessions.

We also hope that the College will be able to strengthen our links with overseas physician colleges, enabling the exchange and sharing of academic resources, while making available academic and training positions for our trainees in overseas centres of excellence. Our College will seek to link up academically with a wider range of overseas professional colleges, not just in the UK, but in other countries as well.

We will introduce simple, point of care guidelines, relevant to our country, based on best evidence, which are available at the bedside to all doctors at a glance. This is integrally linked to ensuring the highest standards of medical care and safety. CPD and CME forms an important part of this, and we also need to strengthen the mechanisms for clinical governance in our practice, moving eventually towards a system of appraisal by our peers, and revalidation.
I would like to see our College play a greater role in enhancing the quality of postgraduate training, by promoting closer interactions between our College and the Postgraduate Institute of Medicine. Our College should also play a greater role in defining the future roles of physicians, generalists, and finer specialists, to fulfil the needs of the Ministry of Health, other state sector institutions, and the private sector. There is a great need to project the requirements of physicians of different subspecialties in the future, taking into account attrition, as well as expanding demands of patients for high quality care. This will require a closer relationship between physicians and policymakers in the Ministry of Health, keeping the needs and aspirations of the patients of this country as our priority.

The job of a physician is an extremely busy one. We often juggle several jobs at once. As a result, we face many ethical dilemmas. Time is often limited, and we battle to finish our tasks through the day, hoping to find a little time to spend with our families. The public is quick to criticise, but slow to understand or acknowledge the commitment that most of us make on their behalf. The irony of this is that we are often criticised or found fault with whatever we do. If we spend too little time, we are thought to be selfish and greedy, if we spend too much, queries are raised about our competence. We are often judged by worst of us, rather than the best of us. This is because a few bad eggs sully the basket. We are often accused of charging excessively, although most of the time our fees are the lowest among equivalent professions. Temptation is easy to yield to, and ethical boundaries, once crossed, become easy to cross again. Once we get on the slippery slope of dishonestly, it is hard to restore our integrity and dignity. We should seek not to judge, rather to understand, the compelling reasons which make some of us do what we do.

How do we strike a balance? How do we show the public that we do self-regulate, that our profession is governed and accountable? We must show society that our practice meets the highest standards. Our College should take leadership in developing a framework for self-regulation, providing guidance to our membership and our trainees. In this regard, the senior members of the College, our teachers, and mentors, have an important role to play, to guide and support the younger members with their wisdom, acting as role models for all of us, while setting the standards for us to measure ourselves by.

Our College has an important role in bringing its members together, as individuals and professionals, to share a part of their social lives with each other. Apart from being enjoyable and entertaining, these 
opportunities for fellowship makes us work together better, and provide more concerted and coordinated care. Crossing the districts for regional meetings brings about more than just the dissemination of knowledge; it binds people together, makes them share their different cultural values, beliefs, and traditions. Indirectly, it also helps us understand the health beliefs and practices of other cultures, enabling us to adapt our methods to make our paradigm of care more acceptable to our patients. The pandemic has placed a restriction on the conventional opportunities for interaction but has opened up different platforms for sharing of ideas, using social media. Diversity brings strength to the physician community, reminding us that though we may be different in some ways, culturally or ideologically, we have more to bring us together than to divide us. It is sometimes sad to see that diversity results in division, especially on social media platforms where it is easy to say careless things which may cause hurt, hiding behind the mask of anonymity. It is important for us to realise the importance of respecting the views of others, of not hurting their cultural sensitivities, while preserving the freedom of expression of scientifically valid views, whatever the medium for communication we use. Our College should play a leading role in ensuring equality and diversity of our membership. Notwithstanding the obstacles placed by the pandemic, we will attempt to hold several regional meetings this coming year, with many other events streamed with local satellite meetings. We also hope to introduce a Fellow's Day, giving an opportunity for our fellows, old and new, to meet and mingle. We also hope to introduce a forum for our trainee physicians, to enable them to generate and share new ideas, while helping them develop networks with trainee physicians across the globe.

Our College has a great history and has achieved a lot. We are proud of what each of us has contributed to make our College what it is, and indeed our College has a great role to play, in the practice of physicians in this country. While being proud, we must also be introspective, critical when needed. We must become more aware of our limitations and shortcomings and try to put things right where we can. We need to make our voice heard loud and clear, letting everyone know that we stand for great ideals, emerging as the organisation which sets the standards for our practice, while also championing the cause of the patients. Perhaps at times we have become too exclusive; we need to open our doors to our membership, make them feel more inclusive wherever they are, help them and guiding to support their efforts at bringing about better patient care. We must be more austere, in this age where money and resources are scarce.
Based on what I have said above, let me spend a few minutes to outline what we are, and what society expects of us, as good physicians. The care of our patients is our highest concern. We have a responsibility to them to be competent, to keep our professional knowledge and skills up to date. It is our duty to take prompt action if we think patient safety is being compromised. We must establish and maintain good partnerships with our patients and colleagues. We must maintain trust in ourselves, and our profession, by being open and honest, and by acting with integrity. Our College has an important responsibility in supporting our membership to be good physicians, by guiding us and supporting us to fulfil these responsibilities to our patients.

In supporting our members to practice better medicine, to become better physicians, we directly improve patient care. But should we do more? As a college, I believe we could reach out to the community more, initiating healthcare projects which directly benefit patient care. Perhaps we could work together to develop infrastructure and facilities in the less developed, impoverished parts of our country? Perhaps we could campaign to draw in funding from the corporate sector to undertake social responsibility projects, through which we develop facilities where they are needed most? These are difficult and ambitious tasks, but with perseverance and commitment, they are not beyond our reach.

The roadmap for our College should not be drawn for just a year or two. We need to look far into the future; drawing our path with a vision of what we want to be some day. We all have dreams and wishes, for ourselves, for our patients, and for our College. A few of these dreams and wishes come true, and many do not, but that should not stop us from dreaming, and wishing.

Let me end with a simple wish for this year, and beyond. A wish that we can easily make come true. I wish that we be blessed with divine discontent. Not quite satisfied with what we have achieved, always wanting more, always wanting to do better. Always wanting to do more for ourselves, to achieve greater heights as academics and professionals; always wanting more for our College, in terms of leadership and advocacy, and academic and professional excellence; and most importantly, wanting to give back more to the community at large, to our patients, who place their lives in our hands.

I thank you for the honour you have given me, and the trust you have placed in me. I pledge to do my best for our College. And I thank you for patiently listening. 